\title{
BIM 技术在装配式建筑及传统建筑设计中的有效应用
}

The Effective Application of BIM Technology in Assembly Architecture and

\author{
Traditional Architecture Design \\ 叶敏盛
}

Minsheng Ye

36220119XXXXXX773X

中国・江西 宜春 336000

36220119XXXXXX773X

Yichun, Jiangxi, 336000, China
【摘要】目前, 中国装配式建筑逐渐成为建筑领域研究的热点。论文主要分析了 BIM 技术 在装配式建筑及传统建筑设计中的有效应用。

【Abstract \At present, China's fabricated buildings have gradually become a research hotspot in the field of architecture. The article mainly analyzes the effective application of BIM technology in fabricated buildings and traditional architectural design.

【关键词】装配式建筑设计;传统建筑设计;BIM 技术; 应用

【Keywords】 prefabricated building design; traditional architectural design; BIM technology; application

【DOI】10.36012/etr.v2i2.1079

\section{1 装配式建筑与传统建筑的差异性}

装配式建筑的装配形式在传统建筑基础上进行了优化, 改善了传统建筑的不足, 如施工周期长、人力成本高、易产生 扬尘、噪声和污水等 ${ }^{[1]}$ 。与传统建筑相比, 装配式建筑具有很 多优势: 构件可以标准化大量生产, 不易受天气变化的影响, 不易出现施工材料浪费问题。并且, 在装配式构件进入现场装 配后, 可以减少很多施工工序, 构件一般在工厂进行生产, 无 须大量人力进行支持, 施工人员的劳动强度有所降低。同时, 由于叠合板做楼板底膜, 外挂板做剪力墙的一侧模板, 这就会 节省很多模板。现阶段, 中国建筑行业处于产业现代化提升阶 段, 装配式建筑取得了很大的突破, BIM 技术的应用逐渐成为 建筑产业信息化的关键 ${ }^{[1]}$ 。

\section{BIM 技术在建筑设计中的有效应用}

\section{1 在建筑空间规划中的应用}

在装配式建筑设计中，空间规划是确定建筑产品地点后 的第一步, 其主要内容是分析建筑产品的占地面积、地形和走 势, 直接关系着建筑产品的外形和走向, 在施工场地地形复杂 的情况下,建筑空间规划具有重要意义。BIM 技术在建筑空间 规划中的应用, 可以将建筑地点、地形等各项数据和信息, 输 入虚拟平台中, 其能够快速分析建筑所在区域的地形、走势、 坡向和斜率, 针对建筑所在区域建模, 这样设计人员可以从不 同角度分析建筑地点、地形, 为后期建筑设计提供数据支持 ${ }^{[2]}$ 。

\section{2 在构建建筑模型中的应用}

在构建建筑模型的过程中, 设计人员根据输人建筑物物 理条件全面分析建筑物的特征和形态, 反映出建筑工程的质 量、结构、空间变化情况, 针对建筑物进行量化处理, 这样建筑 物的各项数据可以直接存储到建筑模型中, 为设计人员提供 参考, 这样其他设计工种的人员可以进行协同作业, 根据建筑 三维模型进行讨论,不断完善建筑设计。

\section{3 在建筑仿真技术中的应用}

BIM 技术可以针对建筑设计进行虚拟还原, 还具有一定 的仿真功能, 仿真技术可以真实地还原建筑产品的各项数据, 如建筑质量、高程和结构数据等, 为校验建筑产品的各项指标 提供支持, 确保建筑产品使用的安全性 ${ }^{[3]}$ 。

\subsection{BIM 技术对各专业协同设计的影响}

设计人员利用 BIM 技术, 可以确保建筑项目通过整合的 BIM 模型开展协同工作, 通过建筑、结构、水、暖、电、预算等不 同专业模型的深化做好建筑设计工作 ${ }^{[2]}$ 。 BIM 技术的应用取得 了很大突破, 能够体现出传统无法表达的细节, 还有很多复杂 的建筑项目可以在 BIM 平台的基础上完成模拟验算, 实现建 筑设计工作的严谨性。

\section{BIM 技术在装配式建筑中的有效应用}

\section{1 在装配式建筑设计阶段的应用}

在装配式结构设计过程中, 设计人员利用 BIM 技术可以 
准确地检索到各项信息，及时地发现设计问题，优化设计方 案，设计人员还可以在 BIM 模型中导人不同专业的模型, 实 现各个专业信息的合并、交互,为各个专业、业主、建设单位、 施工单位的协同管理提供支持。在建筑设计后期,设计人员可 以将建筑模型导入 BIM 碰撞检查软件中, 根据施工进度进行 施工虚拟模拟, 并检查出碰撞点, 优化设计方案, 避免出现不 必要的返工和设计变更问题。

\section{2 在装配式建筑预制构件生产阶段的应用}

预制构件制造商可以根据设计人员共享的 BIM 模型, 获 取建筑预制构件的各个组件、附件信息，提高预制构件的整体 质量, 还可以直接从 BIM 模型中获取预制构件颜色、材质和 尺寸等各项参数, 制造商根据这些参数指定相应的生产计划, 并将各项参数信息以条形码形式添加到预制构件中, 将 BIM 模型设计和预制构件生产联系起来，还可以利用 3D 打印技 术将 BIM 模型打印出来, 深入分析预制构件的组装、试生产 过程, 对原有的预制构件设计方案的合理性进行检查, 有效地 控制后期返工问题。

\section{3 在装配式建筑施工阶段的应用}

在装配式建筑施工阶段, 相关部门可以根据 BIM 技术虚
拟仿真模拟掌握施工现场的场地布置情况, 针对施工过程做 好正序、倒序模拟, 深入分析施工中各个功能区域的安全性和 相关配置 ${ }^{[3]}$ 。另外, BIM 技术具有可视化功能, 相关人员需要针 对施工现场安全性能做好动力学分析、计算、评估工作, 优化 施工现场安全应急方案。

\section{4 结语}

综上所述, BIM 技术是现代化建筑设计中常用的技术之 一, 其具有协调性、模拟性、可视化等优势,在传统建筑设计和 装配式建筑设计中, 设计人员利用这项技术, 可以获取更多准 确的信息,实现 $2 \mathrm{D}$ 平面图纸转化为“3D-BIM”三维模型, 并 对其进行立体化的管理，为后续工程项目建设的顺利实施提 供保障。

\section{参考文献}

[1]聂庆林.基于 BIM 技术的装配式建筑设计方案的优化及其发 展前景[J].居舍,2020(3):98+100.

[2]曾旭东,周金张否.BIM 技术在建筑设计阶段的正向设计应用 探索[J].西部人居环境学刊,2019,34(6):119-126.

[3].装配式建筑相比传统建筑减少的十项内容 [J].砖瓦,2019(11): 137

\section{5 运行维护阶段的应用分析}

封闭母线由工厂成套生产, 质量较有保证, 运行维护工作

封闭型插接母线占地少，以 $1600 \mathrm{~A}$ 封闭型插接母线为 例, 仅需要 $250 \mathrm{~mm} \times 350 \mathrm{~mm}$ 空间即可正常安装。而如果采用电 缆树干式供电系统, 从配电室引出的约 80 个回路会显得很杂 乱无章, 同时还要增加竖向桥架才能满足要求。减少了电井的 空间,从而增大了建筑的使用面积 ${ }^{[3]}$ 。

\section{3 工期短}

相对于采用封闭型插接母线放射式供电主干线系统, 采 用电缆树干式供电系统, 需要增加桥架安装、增加桥架内约 80 个回路的电缆敷设工作、增加电缆头制作安装等施工内 容。从上表可以看出,采用封闭型插接母线放射式供电主干线 系统可以比采用电缆大幅度缩短工期。

昆明时代之窗写字楼封闭型插接母线安装及电缆安装的 定额人工消耗量经测算如表 1 所示。

表 1 人工消耗量对比表

\begin{tabular}{c|c}
\hline 项目名称 & 人工消耗量/工日 \\
\hline 电缆 & 365 \\
\hline 密集母线 & 236 \\
\hline
\end{tabular}

